\title{
Farming and agricultural consumers' cooperative: challenges and opportunities
}

\author{
Vladimir Nosovi, 2,*, Vyacheslav Zhenzhebir ${ }^{1}$, Ruslan Nurgaziev ${ }^{3}$, Liudmila Sleptsova $^{3}$, and Michail Eryushev ${ }^{4}$ \\ ${ }^{1}$ K.G. Razumovsky Moscow State University of Technologies and Management, Department of Economics and Management, 109004 \\ Moscow, Russia \\ ${ }^{2}$ Academy of the Investigative Committee of the Russian Federation, Department of Humanitarian and Socio-Economic Disciplines, \\ 125080 Moscow, Russia \\ ${ }^{3}$ Saratov State Vavilov Agrarian University, Department of Economic Cybernetics, 410012 Saratov, Russia \\ ${ }^{4}$ Saratov State Vavilov Agrarian University, Department of Project Management and Foreign Economic Activity in the Agricultural \\ sector, 410012 Saratov, Russia
}

\begin{abstract}
The article presents the analysis of the development of peasant farm enterprises and agricultural consumers' cooperatives as possible forms of farmers unification with the purpose of processing and selling their products. Over the past years, the number of peasant farm enterprises has decreased by $35 \%$. The use of linear correlation coefficient has led to the conclusion that the number of peasant farm enterprises has little impact on the number of formed agricultural consumers' cooperatives from the perspective of the federal subjects of the Russian Federation. The study of the correlation between PFE and APC shows a different picture: the correlation is more visible there. In the article we reveal the causes holding the development of farming and agricultural consumers' cooperative, and propose activities that should help to increase the number of peasant farm enterprises and agricultural consumers' cooperatives.
\end{abstract}

\section{Introduction}

The issue of which scale of production - large or small is the most feasible one, is still a subject of a thorough and close review. Frequent disputes and formations of various economic thoughts have always accompanied this process. There is no other theme in Russian, Soviet and international economic literature that would have been addressed in such an immense number of books and pamphlets that describe different approaches to the issue and various lines of thought.

The theory of "stability" of small-peasant farming emerged in the latter half of the XIX century - the first quarter of the XX century in European countries. According to this theory, small-scale agricultural production has precedence over the large-scale production, and, therefore, is more viable.

In Russia this theory was represented by M. TuganBaranovsky [1], S. Bulgakov [2] et al. Professor A. Chayanov, Russian agricultural economist, has also significantly contributed to the theory of peasant economy development $[3,4]$.

To date, the most stable and promising form of business organization in rural regions is peasant farm enterprises (PFE), especially family farms, that should ensure national food security $[5,6]$. Thousands of households in Russia are willing to develop their farmsteads, and with proper support from the government, their overall number can increase by 2.5-3 times compared to the current number.
International experience shows that cooperation of farms, [7] being one of the priorities of the agricultural policy $[8,9,10]$, should promote their development. Russian legislation provides for the establishment and functioning of two types of agricultural cooperatives: producers' (APC) and consumers' (ACC). Agricultural consumers' cooperatives serve as the institute for PFE development [11].

\section{Methods and Materials}

The object of study is peasant farm enterprises and agricultural consumers' cooperatives. Abstract-logical and statistical methods were used in the study. In particular, we used the correlation coefficient to estimate the correlation ratio between the numbers of peasant farm enterprises and agricultural consumers' cooperatives, and the Student t-test to determine its significance. The results of the research are presented in tabular and graphical forms.

\section{Results and Discussion}

According to data provided by the Russian Federal State Statistics Service and presented in Figure 1, there were 205 thousand of peasant farming enterprises in 2018.

\footnotetext{
Corresponding author: novla@list.ru
} 


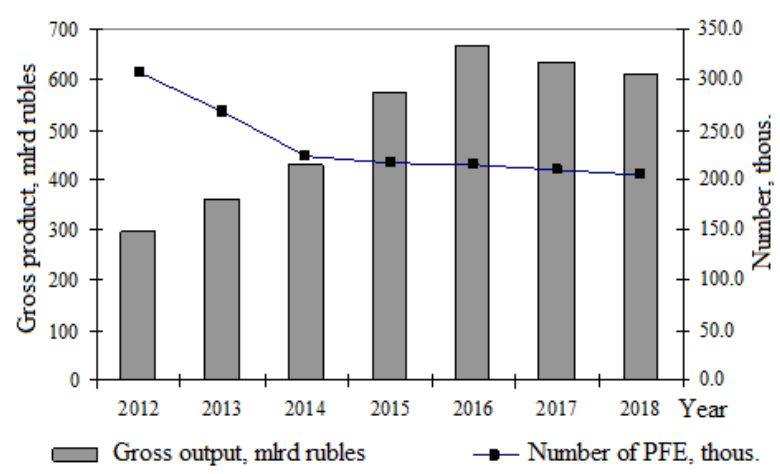

Fig. 1. Farming trend data. Composed by authors in accordance with data provided by the Federal State Statistics Service [12].

However, their number decreased by $33.5 \%$ compared to 2012. The main reason for this is termination of activity of inefficient PFE and their consolidation.

Total PFE land area has increased by $43.2 \%$ and reached $42.1 \mathrm{mln}$ ha. The average amount of PFE land use has increased from 162.8 ha to 240.9 ha.

Nevertheless, in comparison to 2012, the gross agricultural output has doubled and reached 612.5 billion rubles in 2018. The input of PFE to agricultural production also remains stable, which is shown in Figure 2.

As at 1 January 2019, the share of agricultural products, produced by peasant farm enterprises, in total output was $12.5 \%$.

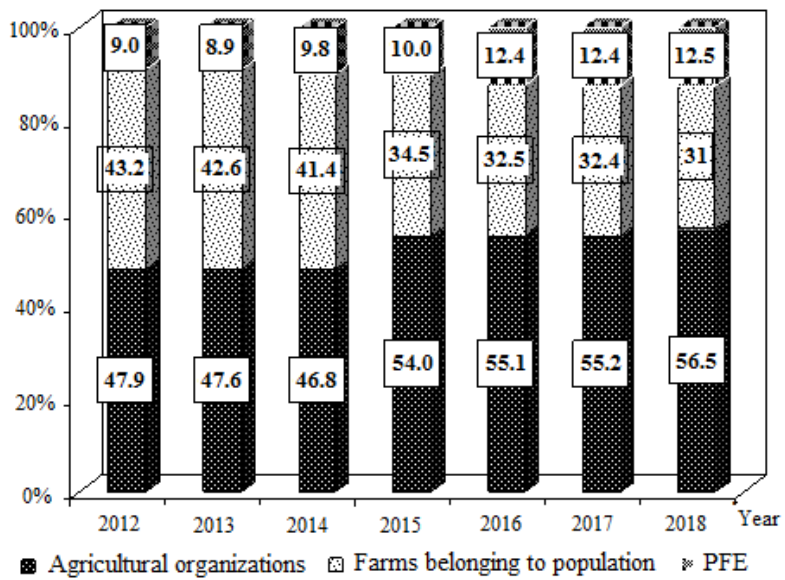

Fig. 2. Agricultural products by farms categories. Composed by authors in accordance with data provided by the Federal State Statistics Service [12].

According to the Russian Federal State Statistic Service, in 2018 farmers harvested $32.8 \mathrm{mln}$ tons of grain, increased production of sunflower (4.2 $\mathrm{mln}$ tons), rapeseed ( $0.4 \mathrm{mln}$ tons), potato $(2.8 \mathrm{mln}$ tons $)$, fruit and berries ( $0.15 \mathrm{mln}$ tons).

The livestock section of PFE also demonstrates the growth of product output. Cow population in farm enterprises has increased by $20 \%$ and production of milk - by more than $30 \%$ compared to 2014 .

These results would not be possible without full government support. Since 2012, the government offers grants to farmers and agricultural consumers' cooperatives, which is the main targeted support measure aimed at creation of new farms and expansion of current productions. More detailed information on this measure is illustrated in Table 1.

Table 1. Grant support.

\begin{tabular}{|c|c|c|c|c|c|c|}
\hline \multirow{2}{*}{ Year } & \multicolumn{3}{|c|}{$\begin{array}{c}\text { Average grant amount, } \\
\text { mIn rubles }\end{array}$} & \multicolumn{3}{c|}{ Number of grantees } \\
\cline { 2 - 7 } & $\begin{array}{c}\text { Novice } \\
\text { farmer }\end{array}$ & $\begin{array}{c}\text { Family } \\
\text { livestock } \\
\text { farm }\end{array}$ & ACC & $\begin{array}{c}\text { Novice } \\
\text { farmer }\end{array}$ & $\begin{array}{c}\text { Family } \\
\text { livestock } \\
\text { farm }\end{array}$ & ACC \\
\hline 2012 & 0.962 & 3.412 & - & 3013 & 788 & - \\
\hline 2013 & 1.045 & 3.7 & - & 2870 & 797 & - \\
\hline 2014 & 1.214 & 3.985 & - & 2441 & 742 & - \\
\hline 2015 & 1.141 & 4.347 & $\begin{array}{c}6.65 \\
9\end{array}$ & 3508 & 953 & 88 \\
\hline 2016 & 1.269 & 5.184 & $\begin{array}{c}7.69 \\
5\end{array}$ & 3665 & 870 & 164 \\
\hline 2017 & 1.8 & 5.95 & 70.7 & 2527 & 727 & 173 \\
\hline 2018 & 2.08 & 7.75 & $\begin{array}{c}15.5 \\
3\end{array}$ & 2353 & 717 & 213 \\
\hline Composed by authors. & \multicolumn{3}{|l|}{} \\
\hline
\end{tabular}

Every year the amount of subsidies increases, as well as the number of grantees. Over the period considered, 20377 peasant farm enterprises were created, and 5594 family livestock farms have implemented their projects due to grants from budgets of all levels. In rural areas, grantees have created more than 48 thousand of new jobs. According to the Russian Federal State Statistics Service, in 2018 the average salary of peasant farm enterprises workers was 9.7 thousand rubles, while in grantees' farms workers' the average salary was about 17 thousand rubles.

Currently, Ministry of Agriculture of the Russian Federation is pursuing an active policy for promotion and development of cooperative ideas in the agricultural sector. Despite the measures taken, the number of agricultural consumers' cooperatives in agroindustrial complex maintenance and involvement of PFE in it is still low, as demonstrated in Figure 3.

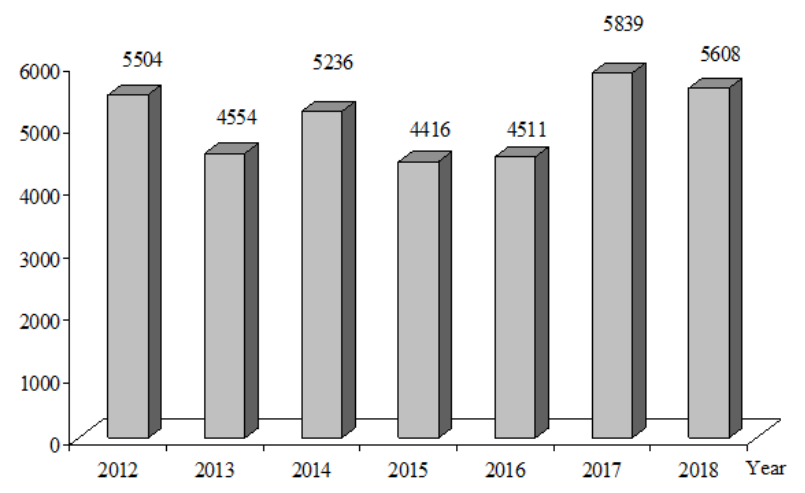

Fig. 3. ACC trend data. Composed by authors in accordance with data provided by the Federal State Statistics Service [12].

Note that PFE are reluctant to unite in agricultural consumers' cooperatives, as can be seen from Table 2 . 
Table 2. Matrix of matching correlation coefficients.

\begin{tabular}{|c|c|c|c|}
\hline Variable & $\begin{array}{l}\text { Number } \\
\text { of ACC }\end{array}$ & $\begin{array}{c}\text { Number } \\
\text { of APC }\end{array}$ & $\begin{array}{l}\text { Number } \\
\text { of PFE }\end{array}$ \\
\hline $\begin{array}{c}\text { Number of agricultural } \\
\text { consumers' } \\
\text { cooperatives }\end{array}$ & 1.000 & 0.1003 & $0.1834^{*}$ \\
\hline $\begin{array}{c}\text { Number of agricultural } \\
\text { producers' } \\
\text { cooperatives }\end{array}$ & - & 1.0000 & $0.4603 *$ \\
\hline Number of PFE & - & - & 1.000 \\
\hline
\end{tabular}

The correlation between the number of PFE and ACC ( $r=0.1834)$ is quite weak, though the correlation coefficient value is significant $\left(t=1.699>t_{\text {tabl }(\alpha=0.1 ; v=93)}=1.663\right)$. The study of the correlation between PFE and APC shows a different picture: the correlation is more visible there.

Indeed, the establishment of agricultural consumers' cooperatives faces problems caused by communication issues, interpersonal relations, individualism, that form the tendency to cooperate among farmers [13].

The following factors constrain the development of agricultural consumers' cooperatives:

- inconsistency of certain rules for consumers' cooperatives in civil and tax law systems;

- insufficient informational support for the development of agricultural consumers' cooperatives;

- lack of necessary understanding of the advantages of consumers' cooperatives on the part of members of cooperatives, including the issue of farmers lacking knowledge and skills of cooperative self-management;

- lack of funds to deposit to cooperative unit trusts, partly because of the low rates of return;

- unavailability of credit resources reflected in their high cost;

- insufficient consideration of specific characteristics of agricultural production during scheduling loan payments and servicing;

- difficulties in products realization related to a high level of competition with large distribution networks and middleman organizations;

- lack of interest in granting support from local authorities, which reflects in difficulties of obtaining scientific, technical and market information and various consulting services.

Currently, only $2 \%$ of farmers are members of consumers' cooperatives. Most progress in the development of consumers' cooperatives has been made in the Lipetsk and Tyumen regions, and in the Sakha Republic (Yakutia).

In order to overcome the existing situation, the Ministry of Agriculture of the Russian Federation changed grant conditions and conditions for job creation by grantees during the year when grant was received to an obligation to create jobs during the period that grant funds are being used - 18 months for novice farmers and 2 years for family farms and consumers' cooperatives. At the same time, conditions for job creation were made easier for novice farmers: instead of 1 job for every 1 mln rubles of grant funds, the novice farmer would have to create 1 new permanent job for every $2 \mathrm{mln}$ rubles of grant funds.

Besides, the maximum amount of grant funds will increase for this category of grantees - novice farmers implementing dairy and beef breeding development projects will receive $5 \mathrm{mln}$ rubles instead of $3 \mathrm{mln}$ rubles, and farmers engaging in other agricultural activities $-3.0 \mathrm{mln}$ rubles instead of $1.5 \mathrm{mln}$ rubles.

List of designation of grant to peasant farm enterprises was extended.

A new way of using grants to all categories of grantees is the possibility to use them for co-payment (no more than 20\%) for the project implemented with the involvement of preferential investment loans (within the preferential loans mechanism).

According to preliminary data provided by the subjects of the Russian Federation, the overall value of a loan portfolio for project implementation could reach 10.0 billion rubles in 2020. Amount of farmers' and cooperatives' private investments could reach 1 billion rubles.

Another meaningful change is the opportunity to extend the period of using grant funds to 6 months upon the occurrence of force majeure, in accordance with the tender commission decision.

In order to provide information and consultative support for farmers and agricultural consumers' cooperatives, competence centers were created in 81 subjects of the Russian Federation, except the Tyumen Region and the Chukotka Autonomous District.

PFE and ACC development stimulates the creation of jobs in rural areas, product output increase, and the supply of domestic food demand. Due to activities of all categories of grantees in rural areas, more than 48 thousand of new permanent jobs have been created in 7 years. According to the Russian Federal State Statistics Service, in 2018 the average salary of peasant farm enterprises workers was 9.7 thousand rubles, while in grantees' farms workers' the average salary was about 17 thousand rubles, which also indicates the efficiency of activities.

In order to create conditions and accelerate the development of small-scale farms, in 2019 the Ministry of Agriculture of the Russian Federation has launched the federal project 'Creation of System for Farmers Support and Agricultural Cooperatives Development', which included additional measures for small farms support.

The federal project funding level is 37.4 billion rubles, including 5.37 billion rubles allocated from the federal budget in 2019.

The main objective of the project is to increase the number of people involved in small and medium businesses by 126 thousand by 2020 . The objective can be achieved by creating new jobs, new peasant farm enterprises and agricultural consumers' cooperatives, and expanding them through the involvement of subjects of small and medium businesses, and a large number of private farm holdings. 


\section{Conclusion}

To sum up, to stimulate the creation of new peasant farm enterprises and agricultural consumers' cooperatives, the following measures, besides the ones proposed by the government, should be implemented:

- audit of regulations of the Russian Federation in order to identify and eliminate unnecessary administrative barriers in peasant farm enterprises' and agricultural consumers' cooperatives' activities;

- development and adoption of programs for the development of agricultural consumers' cooperatives in subjects of the Russian Federation, alongside with provision of additional incentives during the allocation of grants from the federal budget and leasing support;

- ensuring the availability and transparency of the government support procedure for peasant farm enterprises and agricultural consumers' cooperatives;

- promotion of ideas of agricultural consumers' cooperatives among the rural population;

- assistance of local authorities to farmers in the development of agricultural consumers' cooperatives.

\section{References}

[1] S. Bulgakov, Philosophy of Economy, Yale University Press, USA (2000).

[2] M. Tugan-Baranovsky, Modern Socialism in its Historical Development, Swann Sonnenschein, London (1910).

[3] A. Chayanov, The Theory of Peasant CoOperatives, Ohio State University Press, USA (1991).

[4] A. Chayanov, The Theory of Peasant Economy, Homewood, USA, (1966).

[5] T. Yalyalieva, V. Nosov, T. Volkova, M. Tekueva, I. Pavlenko, Issues of Import Substitution in the Agro-Industrial Sector, Res. J. Pharm. Biol. Chem. Sci., 7, 1620-1624 (2016).

[6] Zh. Dibrova, V. Nosov, G. Ovchenkova, E. Karpenko, A. Pilyugina, E. Erkovich, The main directions of the solution of the problem of food security in Russia, IJMET, 9, 387-394 (2018).

[7] K. de Roset, P. Ferrari, K. Knicket, Specialization and economies of scale or diversification and economies of scope? Assessing different agricultural development pathways, J. Rural Stud., 59, 222-223 (2018).

[8] B. Velázquez, B. Buffaria, About farmers' bargaining power within the new CAP, AFE, 5, 16 (2017).

[9] D. Blandford, A. Matthews, EU and US Agricultural Policies: Commonalities and Contrasts, EuroChoices, 18, 4-10 (2019).

[10] E. Ribašauskiene, D. Šumyle, A. Volkov, T. Baležentis, D. Streimikiene, M. Morkunas, Evaluating public policy support for agricultural cooperatives, MDPI, 11, 3769 (2019).
[11] M. Otinova, T. Savchenko, IOP Conf. Ser. Earth Environ. Sci., 274, 012039 (2019).

[12] Federal State Statistics Service, Russian Statistical Yearbook [Electronic resource]. Available at: https://www.gks.ru/publicationsplans.

[13] P. Cush, Á. Macken-Walsh, The Potential for Joint Farming Ventures in Irish Agriculture: A Sociological Review, Eur. Countrys., 8, 33-48 (2016). 